\title{
Association and polymorphism study of seven candidate genes with reproductive traits in three pig breeds in Hungary
}

\author{
Ágnes Hunyadi-Bagi ${ }^{1}$ Péter Balogh², Krisztina Nagy and Szilvia Kusza ${ }^{1 凶}$ \\ ${ }^{1}$ Institute of Animal Science, Biotechnology and Nature Conservation, University of Debrecen, Debrecen, Hungary; ${ }^{2}$ Institute of Sectoral Eco- \\ nomics and Methodology, University of Debrecen, Debrecen, Hungary
}

\begin{abstract}
Seven genes (BF, EGF, ESR, FSHB, H2AFZ, LEP and PRLP) were studied as candidate gene influencing eleven reproduction traits (interval between litters (IBL), percent of litter (PL), number of litters (NL), number of piglets born dead (NBD), number of piglet born alive (NBA), total number born (TNB), mean of born alive (MBA), mean of born dead (MBD), mean of born total (MBT), mean of piglets at 21 days of age (M21D) and growth rate (GR) in three pig breeds (Hungarian Large White (HLW), Duroc and Pietrain) by PCR-RFLP. Based on the observed vs. expected genotypes frequencies populations across loci were in Hardy-Weinberg equilibrium $(P>0.05)$. In case HLW breed ESR and FSH $\beta$ genes were in disequilibrium. Association study suggested that only EGF gene showed significant influence on the trait NBA and TNB. The AA genotype are preferable for sows, associated with higher NBA and TNB. The longest IBL, and the highest NL is associated with $A B$ and $A A$ genotype of EGF gene. IBL is significantly shorter in case of pigs with $A B$ and $A A$ alleles than BB alleles of PRLP genes. Selection for these SNPs could improve the reproductivity in the studied breeds.
\end{abstract}

Key word: reproduction traits, pig, polymorphism, genes, Hungary

Received: 09 September, 2015; revised: 19 February, 2016; accepted: 24 February, 2016; available on-line: 26 April, 2016

\section{INTRODUCTION}

The number of piglet borned total and alive per sow is an important trait for pig breeders. Thus improvement of reproductive traits are the most important factor in the pig production. Molecular technics can provide methods to select directly for genes influencing these traits. The heritabilities for litter size and piglet survival are relatively low, however genetic variability still exists to increase litter size. Increasing the number of pigs weaned per sow will increase economic returns for pig procedures (Rotschild et al., 1996).

Physiologically roles of gene proberdin (BF) are such as uterine epithelium growth (Hasty et al. 1993). Buske and coworkers (2005) studied the polymorphism of gene $\mathrm{BF}$ in German commercial pig (Large White X Landrace) X Leicoma sows) and found the following allele frequencies: 0.11 (A) and 0.89 (B).

Epidermal growth factor (EGF) plays important role in the regulation of cell growth. The EGF receptor system is involved in regulating different processes in the cells, the proliferation and differentiation in endometrial and oviductal tissues (Wollenhaupt et al., 2002). It is a candidate gene for reproduction traits as well, in Chinese breeds, Landrace, Large White, and Pietrain, which are highly differ in litter size, also had significantly different EGF genotypic frequencies (Mendez et al., 1999).

The estogen receptors (ESR) involve estrogens that stimulate protein synthesis in cells and has significant influence on the differentation of vaginal epithelium and uterine endometrium (Sundarrajan et al., 1999). Various polymorphisms were described by several authors (Rotschild et al., 1991; Drögemüller et al., 2000; Drögemüller et al., 2001) and also about its effect on the reproductive traits (Rotschild et al., 1991; Linville, 2001; Matoušek, 2003).

The follicle stimulating hormone (FSH) has two different subunits: a common $\alpha$ and a hormone-specific $\beta$ (Pierce \& Parsons, 1981). The two subunits are encoded by two different genes and synthesided separately from each other.

There was a 4 bp deletion/insertion in intron 2 detected in H2AFZ histone family gene and a PCRBsu151-RFLP was established to detect this variation in Large White and Meishan pigs. In 4th dam line of Chinese lean-type new lines pigs, the females had less piglets born alive with $\mathrm{AA}$ then those with $\mathrm{AB}$ or $\mathrm{BB}$ genotype (Zhang et al., 2009).

Leptin (Lep) was originally identifield following physical mapping of this gene in case of obese in mice (Zhang et al., 1994). There were described different single-base polymorphisms in the pig leptin gene (Stratil et al., 1997; Jiang \& Gibson 1998; Kennes et al., 2001). A deficiency in leptin or the leptin receptor causes disturbances in the reproductive functions in rodent models (Zucker \& Zucker, 1961).

Prolactine hormone is involved in several different endocrine activities, especially in the reproductive processes. The action of the gene is mediated by its receptor (PRLR) (Barber et al., 1992). The two different alleles, A and $B$, were shown significant effect on ejaculate volume and concentration of sperm between boars of different PRLR genotypes (Kmiec \& Terman, 2006).

The aim of this study was to examine the polymorphism of BF, EGF, ESR, FSH $\beta$, LEP, PRLP and PRLR genes and their association on reproductive traits in three different breeds if pig: Hungarian Large White, Duroc and Pietrain. These breeds were not genotyped

e-mail: kusza@agr.unideb.hu

Abbreviations: BF, proberdin; EGF, epidermal growth factor; ESR, estogen receptor; FSHB, follicle stimulating hormone; LEP, leptin; $\mathrm{H} 2 \mathrm{AFZ}$, histone $\mathrm{H} 2 \mathrm{~A}$ isoprotein; PRLP, prolactine receptor; IBL, interval between litters; $\mathrm{PL}$, percent of litter; $\mathrm{NL}$, number of litters; NBD, number of piglets born dead; NBA, number of piglet born alive; TNB, total number born; MBA, mean of born alive; MBD, mean of born dead; MBT, mean of born total; M21D, mean of piglets at 21 days of age; GR, growth rate; HLW, Hungarian Large White; PCR-RFLP, polymerase chain reaction-restriction fragment length polymorphism 
previously for this genes. Thus, our results could be useful for the breeders in their selection schemes for their breeds.

\section{MATERIALS AND METHODS}

Animals and studied traits. The population of pigs sampled in this work was kept at the Hódmezö-Gazda Ltd Station, in Hungary.

The total number of the studied animals were 117 from three breeds: Hungarian Large White ( $\mathrm{n}=93$ ), Duroc $(n=9)$ and Pietrain $(n=15)$.

Traits included were the followings: interval between litters (IBL), percent of litter (PL), number of litters $(\mathrm{NL})$, number of piglets born dead (NBD), number of piglet born alive (NBA), total number born (TNB), mean of born alive (MBA), mean of born dead (MBD), mean of born total (MBT), mean of piglets at 21 days of age (M21D) and growth rate (GR).

Studied genes. Pigs were genotyped for seven candidate genes. The major genes in this study are: the follicle stimulating hormone gene (FSH $\beta$ ), histone $\mathrm{H} 2 \mathrm{~A}$ isoprotein gene (H2AFZ), prolactin receptor gene (PRLP), leptin protein hormone gene (LEP), proberdin protein gene $(\mathrm{BF})$, estrogen receptor gen (ESR) and epidermal growth factor gene (EGF).

DNA isolation, genetic analysis. Genomic DNA was extracted from total blood by Zsolnai \& Orbán (1999) method.

Polymorphism characterization for the studied genes alleles was performed by PCR-AS and PCR-RFLP methods as described by Jiang \& Gibson (1998) (BF A allele and B allele), Mendez et al. (1999) (EGF A allele and B allele), Short et al. (1997) (ESR A allele and B allele), Zhang et al. (2009) (H2AZ A allele and B allele), Linville et al. (2001) (FSHB A allele and B allele), Neuenschwander et al. (1996) (LEP A allele and B allele) and Gajdócsi et al. (2008) (PRLP A allele and B allele), respectively.

Statistical analysis. The allele and genotype frequencies of the different genes were estimated by direct counting and the differences of the observed and expected frequencies of genotypes were tested using Chisquare $\left(\chi^{2}\right)$ test in order to verify if the population was in Hardy-Weinberg equilibrium.

All the measurement variables were analysed using univariate analysis of variance with SPSS 22.0 program. Fix factors were the breed and genotype at the appropriate locus. We calculated the Estimated Marginal Means and used Bonferroni adjustment for multiple comparisons (Lenth \& Herve, 2015).

\section{RESULTS}

In this study, two alleles were identified in sow herd, $\mathrm{C}$ and $\mathrm{T}$ for LEP gene and $\mathrm{A}$ and $\mathrm{B}$ for the all of other ones (BF, EGF, ESR,FSH $\beta$, H2AFZ, PRLP). The genotypes, namely $\mathrm{CC}, \mathrm{CT}, \mathrm{TT}$ and $\mathrm{AA}, \mathrm{AB}$, and $\mathrm{BB}$ were observed. Allele frequencies in different breeds are presented in Table 1.

Populations of analysed sows were in Hardy-Weinberg equilibrium $(P>0.05)$. Only in three cases Hardy-Weinberg disequilibrium were observed, caused by the differences between the observed and expected frequencies of gens ESR, FSH $\beta$ in HLW breed and gene EGF in Pietrain breed.

Allele frequencies are various in the sows. The frequency of the A and B alleles were 0.10 and 0.90 in the case of $\mathrm{BF}$ and ESR genes. The most similar frequencies are 0.44 of $\mathrm{A}$ and 0.56 of $\mathrm{B}$ alleles in H2AZ gene.

The significant influence of the seven genes was on the number of piglets born dead (NBD), mean of born dead (MBD) and mean of piglets at 21 days of age (M21D) $(P<0.05)$ all of the seven genes due to the breeds (Table 2). There were statistically significant differences between the Hungarian Large White and the Duroc or Pietrain pigs. The significant differences in this three traits (NBD, MBD and M21D) showed all of the seven genes due to the breeds.

\section{BF}

Two genotypes (AB and $\mathrm{BB}$ ) were indentified by PCR-RFLP in pig populations studied for proberdin (BF) gene. The homozygote individuals AA are missing in case of BF gene, in the three breeds at all. The statistical analysis shows, that the Hungarian Large White pigs had significantly less dead piglets (NBD) than Duroc ( -3.34 piglets, $P=0.013)$ or Pietrain sows $(-4.72$ piglets, $P<0.001)$, this result led to significant differencies also in trait: mean of born dead $(-0.76$ piglets, $P=0.001 ;-1.06$ piglets, $P<0.001)$.

Significantly higher mean of piglets at 21 days of age (M21D) were showed in Hungarian Large White sows, 1.19 more piglets at the 21 days of age than Pietrain $(P=0.01)$, and 1.59 more than Duroc $(P=0.001)$.

Significantly higher mean of born alive piglets (MBA) were showed in Hungarian Large White sows, 2.03 more piglets than Pietrain $(P=0.004)$, and 1.91 more piglets than Duroc $(P=0.014)$.

\section{EGF}

Only one gene, the EGF represented influence on trait NBA and TNB. The two alleles (AB, BB) of EGF gene were detected from the three breeds and the AA was only in HLW breed. Differences are between the $\mathrm{AA}-\mathrm{BB}$ and $\mathrm{AA}-\mathrm{AB}$ alleles and the genotypes have influence on the number of piglet born alive (NBA), total number born (TNB) (Table 3). The homozygote AA were associated with 39.44 more and 48.19 more than the homozygous $\mathrm{BB}(P=0.001)$ and the heterozygous $\mathrm{AB}$ genotype $(P=0.003)$. The same result was shown in the trait TNB: the AA genotypes were associated significant higher total number of piglets, than $\mathrm{BB}(+36.02$ piglets, $P=0.005)$ or $\mathrm{AB}(+44.98$ piglets, $P=0.008)$ genotypes.

The EGF alleles also had influence on other traits: interval between litters (IBL), number of litters (NL). The data suggested, that in case of the AB allel was the longest the interval between litters (IBL). Differences between the AB-BB (54.32 days, $P=0.001)$ and $\mathrm{AB}-\mathrm{AA}$ (59.47 days, $P=0.005$ ) alleles were significant in IBL trait.

The highest number of litters (NL) was associated with AA genotype. Differences between the AA$\mathrm{AB}(+3.22$ litters, $P=0.018)$ and $\mathrm{AA}-\mathrm{BB}(+2.27$ litters, $P=0.031)$ alleles were significant in NL trait.

In the population, the Pietrain breed had the longest interval between litters (IBL). There were significant differences between Pietrain and HLW (+80.56 days, $P<0.001)$ or Pietrain and Duroc (+89.89 days, $P<0.001)$ breeds.

The statistical analysis shows, that the Hungarian Large White pigs had significantly less dead piglets (NBD) than Pietrain sows $(-4.85$ piglets; $P=0.016)$, this result led to significant differencies also in trait, mean of born dead (MBD) ( -1.51 piglets; $P<0.001)$. Duroc sows also had higher MBD piglets than HLW sows 
Table 1. Distribution of genotype of studied genes and allele frequencies values

\begin{tabular}{|c|c|c|c|c|c|c|c|c|c|c|c|c|c|c|c|c|}
\hline \multirow[t]{2}{*}{ Gene } & \multirow[b]{2}{*}{$\mathrm{n}$} & \multicolumn{5}{|c|}{ Hungarian Large White } & \multicolumn{5}{|c|}{ Duroc } & \multicolumn{5}{|c|}{ Pietrain } \\
\hline & & AA & BB & $A B$ & $\begin{array}{l}x^{2} \\
\text { d.f. }=1\end{array}$ & $P$ & AA & BB & $A B$ & $\begin{array}{l}x^{2} \\
\text { d.f. }=1\end{array}$ & $P$ & AA & BB & $A B$ & $\begin{array}{l}x^{2} \\
\text { d.f. }=1\end{array}$ & $P$ \\
\hline \multirow[t]{4}{*}{$\mathrm{BF}$} & & - & 67 & 26 & 2.46 & 0.117 & - & 6 & 3 & 0.36 & 0.549 & - & 12 & 3 & 0.19 & 0.667 \\
\hline & \multirow{2}{*}{ an } & $A$ & B & & & & $A$ & B & & & & $A$ & B & & & \\
\hline & & 0.14 & 0.86 & & & & 0.17 & 0.83 & & & & 0.10 & 0.90 & & & \\
\hline & $\mathrm{n}$ & AA & BB & $A B$ & $\begin{array}{l}x^{2} \\
\text { d.f. }=2\end{array}$ & $\mathrm{P}$ & AA & BB & $A B$ & $\begin{array}{l}x^{2} \\
\text { d.f. }=1\end{array}$ & $P$ & AA & BB & $A B$ & $\begin{array}{l}x^{2} \\
\text { d.f. }=1\end{array}$ & $\mathrm{P}$ \\
\hline \multirow[t]{4}{*}{ EGF } & & 6 & 62 & 25 & 2.28 & 0.131 & - & 7 & 2 & 0.14 & 0.708 & - & 14 & 1 & 0.02 & 0.894 \\
\hline & \multirow{2}{*}{ an } & $A$ & B & & & & $A$ & B & & & & A & B & & & \\
\hline & & 0.21 & 0.79 & & & & 0.11 & 0.89 & & & & 0.03 & 0.97 & & & \\
\hline & $\mathrm{n}$ & AA & $\mathrm{BB}$ & $A B$ & $\begin{array}{l}x^{2} \\
\text { d.f. }=1\end{array}$ & $P$ & $\mathrm{AA}$ & $\mathrm{BB}$ & $A B$ & $\begin{array}{l}\text { x2 } \\
\text { d.f.=n.a. }\end{array}$ & $P$ & AA & $\mathrm{BB}$ & $A B$ & $\begin{array}{l}x^{2} \\
\text { d.f. }=1\end{array}$ & $P$ \\
\hline \multirow{4}{*}{ ESR } & & 23 & - & 70 & 33.87 & 0.000 & 9 & - & - & - & - & 12 & - & 3 & 0.19 & 0.667 \\
\hline & 2 & A & B & & & & A & B & & & & A & B & & & \\
\hline & an & 0.62 & 0.38 & & & & 1 & - & & & & 0.90 & 0.10 & & & \\
\hline & $\mathrm{n}$ & $\mathrm{AA}$ & $\mathrm{BB}$ & $A B$ & $\begin{array}{l}x^{2} \\
\text { d.f. }=2\end{array}$ & $P$ & $\mathrm{AA}$ & $\mathrm{BB}$ & $A B$ & $\begin{array}{l}x^{2} \\
\text { d.f.=n.a. }\end{array}$ & $P$ & AA & $\mathrm{BB}$ & $A B$ & $\begin{array}{l}x^{2} \\
\text { d.f. }=1\end{array}$ & $P$ \\
\hline \multirow[t]{4}{*}{$\mathrm{FSH} \beta$} & & 3 & 37 & 53 & 9.26 & 0.002 & - & 9 & - & - & - & - & 9 & 6 & 0.94 & 0.333 \\
\hline & 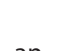 & A & B & & & & A & B & & & & A & B & & & \\
\hline & ain & 0.32 & 0.68 & & & & - & 1 & & & & 0.20 & 0.80 & & & \\
\hline & $\mathrm{n}$ & $\mathrm{AA}$ & BB & $A B$ & $\begin{array}{l}x^{2} \\
\text { d.f. }=2\end{array}$ & $P$ & $\mathrm{AA}$ & BB & $A B$ & $\begin{array}{l}x^{2} \\
\text { d.f. }=2\end{array}$ & $P$ & $\mathrm{AA}$ & $\mathrm{BB}$ & $A B$ & $\begin{array}{l}x^{2} \\
\text { d.f. }=1\end{array}$ & $P$ \\
\hline \multirow[t]{4}{*}{$\mathrm{H} 2 \mathrm{AFZ}$} & & 69 & 4 & 20 & 2.36 & 0.125 & 2 & 3 & 4 & 0.09 & 0.764 & 11 & - & 4 & 0.36 & 0.551 \\
\hline & an & A & B & & & & A & B & & & & A & B & & & \\
\hline & & 0.85 & 0.15 & & & & 0.44 & 0.56 & & & & 0.87 & 0.13 & & & \\
\hline & $\mathrm{n}$ & $\pi$ & $\mathrm{CC}$ & $\mathrm{TC}$ & $\begin{array}{l}x^{2} \\
\text { d.f. }=2\end{array}$ & $P$ & $\pi$ & $\mathrm{CC}$ & $\mathrm{TC}$ & $\begin{array}{l}x^{2} \\
\text { d.f. }=1\end{array}$ & $P$ & $\pi$ & $\mathrm{CC}$ & $\mathrm{TC}$ & $\begin{array}{l}x^{2} \\
\text { d.f. }=2\end{array}$ & $P$ \\
\hline \multirow[t]{4}{*}{ LEP } & & 72 & 3 & 18 & 1.79 & 0.180 & 6 & - & 3 & 0.36 & 0.549 & 9 & - & 6 & 0.94 & 0.333 \\
\hline & an & $\mathrm{T}$ & $C$ & & & & $T$ & $C$ & & & & $T$ & C & & & \\
\hline & dn & 0.87 & 0.13 & & & & 0.83 & 0.17 & & & & 0.80 & 0.20 & & & \\
\hline & $\mathrm{n}$ & $\mathrm{AA}$ & BB & $A B$ & $\begin{array}{l}x^{2} \\
\text { d.f. }=2\end{array}$ & $P$ & $\mathrm{AA}$ & BB & $A B$ & $\begin{array}{l}x^{2} \\
\text { d.f. }=1\end{array}$ & $P$ & $\mathrm{AA}$ & BB & $A B$ & $\begin{array}{l}x^{2} \\
\text { d.f. }=2\end{array}$ & $P$ \\
\hline \multirow[t]{3}{*}{ PRLP } & & 40 & 16 & 37 & 2.02 & 0.155 & - & 6 & 3 & 0.36 & 0.549 & 6 & 3 & 6 & 0.42 & 0.519 \\
\hline & 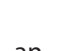 & A & B & & & & A & B & & & & A & B & & & \\
\hline & & 0.63 & 0.37 & & & & 0.17 & 0.83 & & & & 0.59 & 0.41 & & & \\
\hline
\end{tabular}

$\mathrm{n}$ : number of genotype; an: allele frequencies

$(+0.734$ piglets; $P=0.01)$. Significantly higher mean of piglets at 21 days of age (M21D) were showed in Hungarian Large White sows than Duroc sows (+1.43 piglets; $P=0.017)$.

\section{ESR}

Two alleles (AA, AB) of ESR gene were detected under this study. There were not found any sows with BB 
Table 2. Average values of analysed reproduction traits in sows with different breeds

\begin{tabular}{|c|c|c|c|c|c|}
\hline Gene & Trait & Breed & Lsmean & SE & Group \\
\hline \multirow[t]{12}{*}{$\mathrm{BF}$} & NBD & HLW & 1.66 & 0.36 & $a$ \\
\hline & & duroc & 5.00 & 1.09 & $b$ \\
\hline & & pietrain & 6.38 & 1.00 & $b$ \\
\hline & MBA & HLW & 11.08 & 0.21 & $b$ \\
\hline & & duroc & 9.18 & 0.63 & $a$ \\
\hline & & pietrain & 9.05 & 0.57 & $\mathrm{a}$ \\
\hline & MBD & HLW & 0.30 & 0.07 & a \\
\hline & & duroc & 1.06 & 0.20 & $b$ \\
\hline & & pietrain & 1.36 & 0.18 & $b$ \\
\hline & M21D & HLW & 9.93 & 0.13 & $b$ \\
\hline & & duroc & 8.34 & 0.41 & $\mathrm{a}$ \\
\hline & & pietrain & 8.74 & 0.37 & $\mathrm{a}$ \\
\hline \multirow[t]{12}{*}{ EGF } & $\mathrm{IBL}$ & HLW & 166.53 & 4.98 & $\mathrm{a}$ \\
\hline & & duroc & 157.20 & 12.67 & $\mathrm{a}$ \\
\hline & & pietrain & 247.09 & 16.36 & $b$ \\
\hline & NBD & HLW & 1.72 & 0.50 & $\mathrm{a}$ \\
\hline & & duroc & 4.86 & 1.27 & $a b$ \\
\hline & & pietrain & 6.57 & 1.63 & $\mathrm{~b}$ \\
\hline & MBD & HLW & 0.31 & 0.09 & $\mathrm{a}$ \\
\hline & & duroc & 1.04 & 0.23 & $b$ \\
\hline & & pietrain & 1.82 & 0.29 & $\mathrm{~b}$ \\
\hline & M21D & HLW & 10.01 & 0.18 & $\mathrm{~b}$ \\
\hline & & duroc & 8.59 & 0.47 & $\mathrm{a}$ \\
\hline & & pietrain & 9.53 & 0.61 & $a b$ \\
\hline \multirow[t]{15}{*}{ PRLP } & $\mathrm{IBL}$ & HLW & 166.93 & 3.10 & $a$ \\
\hline & & duroc & 157.80 & 9.71 & a \\
\hline & & pietrain & 202.45 & 7.47 & $b$ \\
\hline & NBD & HLW & 2.00 & 0.36 & $\mathrm{a}$ \\
\hline & & duroc & 5.17 & 1.12 & $b$ \\
\hline & & pietrain & 6.22 & 0.86 & $\mathrm{~b}$ \\
\hline & MBA & HLW & 11.04 & 0.20 & $\mathrm{~b}$ \\
\hline & & duroc & 9.02 & 0.64 & $\mathrm{a}$ \\
\hline & & pietrain & 9.50 & 0.49 & $a$ \\
\hline & MBD & HLW & 0.35 & 0.07 & $\mathrm{a}$ \\
\hline & & duroc & 1.07 & 0.20 & $\mathrm{~b}$ \\
\hline & & pietrain & 1.42 & 0.16 & $\mathrm{~b}$ \\
\hline & M21D & HLW & 9.87 & 0.13 & $\mathrm{~b}$ \\
\hline & & duroc & 8.32 & 0.42 & $\mathrm{a}$ \\
\hline & & pietrain & 9.22 & 0.32 & $a b$ \\
\hline
\end{tabular}

genotype at all in the three breeds. The statistical analysis of data of ESR gene showed higher mean 21st day of piglets (+1.49 piglets, $P=0.001)$ and mean of born alive ( +2.06 piglets, $P=0.004 ;+1.59$ piglets, $P=0.033$ ), lower
Table 3. Average values of analysed reproduction traits in sows with different genotypes

\begin{tabular}{|c|c|c|c|c|c|}
\hline Gene & Trait & Allele & Lsmean & SE & Group \\
\hline \multirow[t]{12}{*}{ EGF } & IBL & AA & 159.19 & 12.90 & $a$ \\
\hline & & $A B$ & 218.66 & 13.07 & b \\
\hline & & BB & 164.34 & 5.06 & a \\
\hline & $\mathrm{NL}$ & AA & 7.33 & 0.81 & $b$ \\
\hline & & $A B$ & 4.11 & 0.82 & a \\
\hline & & BB & 5.06 & 0.32 & a \\
\hline & NBA & AA & 89.50 & 9.88 & b \\
\hline & & $A B$ & 41.31 & 10.01 & a \\
\hline & & BB & 50.06 & 3.88 & a \\
\hline & TNB & AA & 90.67 & 10.32 & $b$ \\
\hline & & $A B$ & 45.69 & 10.46 & a \\
\hline & & BB & 54.65 & 4.05 & a \\
\hline \multirow[t]{3}{*}{ PRLP } & $\mathrm{IBL}$ & $A A$ & 159.50 & 6.01 & a \\
\hline & & $A B$ & 207.62 & 6.87 & $b$ \\
\hline & & BB & 160.64 & 6.65 & a \\
\hline
\end{tabular}

number of piglets dead ( -3.65 piglets, $P=0.003 ;-5.45$ piglets, $P<0.001)$ and mean of born dead $(-0.82$ piglets, $P<0.001 ;-1.26$ piglets, $P<0.001)$ in the Hungarian Large White breed compared to Duroc and Pietrain breeds, respectively.

\section{FSH $\beta$}

From the three observed alleles (AA, AB, BB) of FSH $\beta$ gene, the AA was missing in Duroc and Pietrain breeds and the $\mathrm{AB}$ was missing only in Duroc breed. Statistical analysis of data of FSH $\beta$ gene showed higher mean 21 st day of piglets $(+1.22$ piglets, $P=0.026 ;+0.48$ piglets, $P=0.647)$, lower number of piglets dead $(-3.87$ piglets, $P=0.006 ;-4.89$ piglets, $P<0.001)$ and mean of born dead $(-0.85$ piglets, $P=0.001 ;-1.09$ piglets, $P<0.001)$ in the Hungarian Large White breed, than in Duroc and Pietrain breeds, respectively.

\section{H2AFZ}

Three alleles were detected of the H2AFZ gene: AA, $\mathrm{AB}, \mathrm{BB}$. There were not found any Pietrain pig with $\mathrm{BB}$ allel. The statistical analysis of data of $\mathrm{H} 2 \mathrm{AFZ}$ gene showed higher MBA (+2.17 piglets, $P=0.009$; +1.57 piglets, $P=0.041)$, mean 21 st day of piglets $(+1.24$ piglets, $P=0.024$; +0.42 piglets, $P=0.917$ ) and lower number of piglets dead $(-3.97$ piglets, $P=0.004 ;-4.97$ piglets, $P<0.001)$ and mean of born dead $(-0.84$ piglets, $P=0.001 ;-1.18$ piglets, $P<0.001)$ in the Hungarian Large White breed, than in Duroc and Pietrain breeds, respectively.

\section{LEP}

Three alleles were observed (TT, TC and CC) under this study, but the animals with CC were missing in Duroc and Pietrain breeds. The statistical analysis of data of LEP gene showed higher mean 21st day of piglets (+1.59 piglets, $P=0.004$; +0.88 piglets, $P=0.087$ ) and lower number of piglets dead (-3.09 piglets, $P=0.054$; -4.15 piglets, $P<0.001)$ and mean of born dead $(-0.75$ 
piglets, $P=0.005 ;-1.01$ piglets, $P<0.001)$ in the Hungarian Large White breed, than in Duroc and Pietrain breeds, respectively.

\section{PRLP}

There were found three alleles $(\mathrm{AB}, \mathrm{BB}$, and $\mathrm{AA})$ in the population, but there were not any Duroc pigs with AA genotype. The statistical analysis of data of PRLP gene showed higher MBA (+2.02 piglets, $P=0.01 ;+1.55$ piglets, $P=0.014)$, mean 21 st day of piglets $(+1.56$ piglets, $P=0.002$; +0.65 piglets, $P=0.187$ ) and lower number of piglets dead $(-3.17$ piglets, $P=0.024 ;-4.22$ piglets, $P<0.001)$ and mean of born dead $(-0.72$ piglets, $P=0.003 ;-1.07$ piglets, $P<0.001)$ in the Hungarian Large White breed, than in Duroc or Pietrain breeds, respectively. On the trait the interval between litters (IBL) is significantly shorter in case of pigs with $\mathrm{AB}$ or $\mathrm{AA}$ alleles of PRLP genes (Table 3) than the pigs with $\mathrm{BB}$ alleles (-46.98 days, $P<0.001 ;-48.12$ days, $P<0.001)$ and HLW breed had shorter IBL compared to Pietrain breed (-35.52 days, $P<0.001)$.

\section{DISCUSSION}

Nowadays, the genome maps are the opportunity to identify genes to control the reproduction. It helps the work in the pig breeding as well. Detection of exact genes or genetic markers which are in association with litter size in pigs may have major impact on the improvement of reproductive traits by increasing accuracy of selection (Rotschild et al., 1996). In this study we have chosen the most important 11 traits, and the main traits are: number of piglet born alive (NBA), total number born (TNB). Only the EGF gene showed influence on the NBA.

Especially traits are number of piglets born dead (NBD), mean of born alive (MBA), mean of born dead (MBD), mean weight at 21st day (M21D) in our work. Also we chose seven candidate genes for the analysis due to their integral role in several reproductive pathways.

The effect of the maternal breed is very important on the litter size in reproduction studies. In this study we found the effect of the breeds on the traits MBD, NBD and M21D. This result was not estimated, because there were not reported difference in the NBD between Large White and Mukota hybrids sows in another study (Ncube et al., 2003).

Genotype AA of the BF gene was not detected in the studied breeds. Buske and coworkers (2005) found the similar result, frequency of genotype AA was very low (2,4\%) among 123 sows.

We found the AA genotype of the ESR gene quasi exclusively are presented in the population. The BB genotype is not presented in the population at all. It corresponds to other results, where also were studied the same polymorphism in the Large White population. (Matusek, 2003). Also were not possible the NBA analysis in another study due to lack of BB animals (Drögemüller et al., 2001). They found that a trend for animals with one copy of $\mathrm{B}$ allel have increased the number of piglets born alive (NBA). ESR genotypes were not significant in either breed similar to data of Short et al. (1997).

The EGF gene showed significant influence on the traits the number of piglet born alive (NBA), total number born (TNB). This result corresponds with the results of Korwin-Kossakowska (2005), who also studied the same polymorphism in Polish Landrace, Polish Large White and Commercial Line. So the maternal genotype of the EGF gene should be a good candidate gene for NBA and TNB traits.

The other six studied genes have non significant influence on the two main traits (NBA and TNB). It corresponded with the results of other author studied the following genes: follicle stimulating hormone (FSH $\beta$ ), prostaglandin endoperoxide-synthase 2 (PTGS2), prolactin receptor (PRLR), estrogen receptor (ESR), retinol binding protein (RBP4), and also the epidermal growth factor (EGF). They found, these genes had not large effects on litters size in the examined pig population (Linville, 2001). Althougth, this is not true for the EGF gene in our study.

The EGF alleles also had influence on other trais: interval between litters (IBL), number of litters (NL). The data suggested, that in case of the $\mathrm{AB}$ allel is the longest the interval between litters (IBL). The highest number of litters (NL) is associated with AA genotype. So the animals carrying AA genotype is preferable, because had significantly higher NL, and medium long IBL.

A similar frequency of allele C (0.11) of LEP gene was observed in Polish Large White $\mathrm{X}$ Landrace pigs (Terman, 2005). Their results are comparable with the results reported in our study, the analysis of relationship between different genotypes of LEP, and TNB, NBA showed only few, statistically non-significant differences. The homozygous CC pigs are missing in Duroc and Pietrain population, due to the low number of sows in these breeds.

Homozigous AA carrying pigs of H2AFZ gene are associated with 1.23 higher mean of 21 days of age than homozigous BB. Even now the work of Zhang and coworkers (2009), the found the first-parity females in DIV (4th Dam line of Chinese lean-type new lines) with AA genotype had less piglets born alive (NBA), the H2AFZ sould be a good candidate gene of litter size trait.

Allele frequencies and genotype were presented in Table 1 . In this study were found the A allel of PRLP gene was dominant with frequency of 0.59 . In comparison to this result, similar higher frequency of A allele was reported in Landrace and Duroc sows (Drögemüller et al., 2000) and in Large White sows (Putnová et al., 2002). Opposite to this results, B allele (0.81) was dominant in Mong Cai sows in Vietnam (Thuy et al., 2006). On the trait, IBL, pigs with $\mathrm{AB}$ alleles of prolactin receptor gene (PRLP) were the interval significantly shorter than with other genotypes. This trait (IBL) is not so commonly analysed trait. This is a new result of the analysing the reproduction traits. Furthermore we were expected because of other studies (Gajdócsi et al., 2008; Kmieć et al., 2001) that greater number of piglets characterized the sows carrying homozigous AA genotype of PRLP gene. Our datas did not show this expected dependency. Gajdócsi and coworkers (2008) were working with Mangalica and Duroc, and Kmiec et al. (2001) with Polish Landrace. Presumably, because of the different breeds and the low number of Duroc pigs could we not find this correspondence.

In this study we evaluated the polymorphism of seven candidate genes and their associations with eleven traits of high economic impact on the pig husbandry. Many previous studies were focused on some of these traits, but only a few were focused on all traits together. Contrary to the expectations, only one gene, the EGF had effect on the main (NBA, TNB) reproduction traits. Except of the BF and ESR genes, the others showed significant effect on other reproduction traits. The results outlined that selection of major genes may be useful in breeding practise. 


\section{Acknowledgments}

The authors thank Bachelor and Master students for genotyping work. Thanks are due to Academic Editing Service for the English language revision.

\section{REFERENCES}

Barber MC, Clegg RA, Finley E, Vernon RG, Flint DJ (1992) The role of growth hormone, prolactin and insulin-like growth factors in the regulation of rat mammary gland and adipose tissue metabolism during lactation. J Endocrinol 135: 195. http://dx.doi.org/10.1677/ joe. 0.1350195 .

Buske B, Brunsch C, Zeller K, Reinecke P, Brockmann G (2005) Analysis of properdin (BF) genotypes associated with litter size in a commercial pig cross population. I Anim Breed Genet 122: 259-263. http://dx.doi.org/10.1111/j.1439-0388.2005.00528.x.

Drögemüller C, Hamann H, Krieter J, Presuhn U, Wallenburg J, Distl $\mathrm{O}$ (2000) Candidate gene markers connected to litter size in German pigs. 27th Int. Conf. Anim. Genet. Minneapolis. 26.

Drögemüller C, Hamman H, Distl O (2001) Candidate gene markers for litter size in different German pig lines. I Anim Sci 79: 25652570. doi:/2001.79102565x.

Hasty LA, Brockman WW, Lambris JD, Lyttle R (1993) Hormonal regulation of complement factor $\mathrm{B}$ in human endometrium. Am J Reprod Immunol 30: 63-67. http://dx.doi.org/10.1111/j.1600-0897.1995. tb00921.x.

Gajdócsi E, Pataki R, Tempfli K, Bali Papp Á (2008) A prolaktin receptor gén hatása a mangalicák alomméretére AWeth 4: 424-429 (in Hungarian).

Jiang ZH, Gibson JP (1998) Rapid communication: a PCR-RFLP marker at the porcine complement factor B gene locus shows between-population frequency variation. J Anim Sci 76: 1716-1717. doi:/1998.7661716x.

Kennes YM, Murphy BD, Pothier F, Palin MF (2001) Characterization of swine leptin (LEP) polymorphisms and their association with production traits. Anim Genet 32: 215-218. http://dx.doi. org/10.1046/j.1365-2052.2001.00768.x.

Kmieć M, Dybus A, Terman A (2001) Prolactin receptor gene polymorphism and its association with litter size in Polish Landrace. Arch Tierzucht 44: 547-551.

Kmieć M, Terman A (2006) Associations between the prolactin receptor gene polymorphism and reproductive traits of boars. $J$ Appl Genet 47: 139-141. http://dx.doi.org/10.1007/BF03194613

Korwin-Kossakowska A, Kapelański W, Bocian M, Kamyczek M, Sender G, Kurył J (2005) Preliminary study of RBP4, EGF and PTGS2 genes polymorphism in pigs and its association with reproduction traits of sows. Animal Sciences Papers and Reports 23: 95-105.

Lenth RV, Herve M (2015) lsmeans: Least-Squares Means. R package version 2.16. http://CRAN.R-project.org/package=lsmeans

Linville RC, Pomp D, Johnson RK, Rothschild MF (2001) Candidate gene analysis for loci affecting litter size an ovulation rate in swine. J Anim Sci 79: 60-67. doi:/2001.79160x.

Matoušek V, Kernerová N, Kolaříková O, Krŕžzová H, Urban T, Vrtková I (2003) Effect of RYR1 and ESR genotypes on the fertility of sows of Large White breed in elite herds. Czech J Anim Sci 48: 129-133.

Mendez EA, Messer LA, Larsen NJ, Robic A, Rothschild MF (1999) Epidermal growth factor maps to pig chromosome 8. J Anim Sci 77: 494-495. doi:/1999.772494x.

Neuenschwander S, Rettenberger G, Meijerink H, Jorg H, Stranzinger G (1996) Partial characterization of porcine obesity gene (OBS) and its localization to chromosome 18 by somatic cell hybrids. Anim Genet 27: 275-278. http://dx.doi.org/10.1111/j.1365-2052.1996. tb00489.x.

Ncube M, Dzama K, Chimonyo M, Kanengoni A, Hamudikuwanda H (2003) Effect of boar genotype on reproductive performance of the local sows of Zimbabwe. Livestock Research for Rural Development 15 (2).

Pierce JG, Parsons TF (1981) Glycoprotein hormones: structure and function. Annu Rev Biochem 50: 465-495. http://dx.doi.org /10.1146/annurev.bi.50.070181.002341.

Putnová L, Knoll A, Dvoral J, Cepica S (2002) A new HpaII PCR RFLP within the porcine prolactin receptor (PRLR) gene and study of its effect on litter size and number of teats. I Anim Breed Genet 119: 57-63. http://dx.doi.org/ 10.1046/j.1439-0388.2002.00316.x.

Rothschild MF, Larson RG, Jacobson C, Pearson P (1991) PvuII polymorphisms at the porcine estrogen-receptor locus (ESR). Anim Genet 22: 448-448. http://dx.doi.org/ 10.1111/j.1365-2052.1991. tb00715.x.

Rothschild M, Jacobson C, Vaske D, Tuggle C, Wang L, Short T, Eckardt G, Sasaki S, Vincent A, McLaren D, Southwood O, van der Steen H, Mileham A, Plastow G (1996) The estrogen receptor locus is associated with a major gene influencing litter size in pigs. Proc Natl Acad Sci 93: 201-205.

Short TH, Rothschild MF, Southwood OI, McLaren DG, de Vries A, van der Steen A, Eckardt GR, Tuggle CK, Helm J, Vaske DA, Mileham AJ, Plastow GS (1997) Effect of the estrogen receptor locus in reproduction and production traits in four commercial pig lines. I Anim Sci 75: 3138-3142.

Stratil A, Peelman L, Van Poucke M, Cepica S (1997) A HinfI PCRRFLP at the porcine leptin (LEP) gene. Anim Genet 28: 371-372. http://dx.doi.org/ 10.1111/j.1365-2052.1997.tb03272.x.

Sundarrajan C, Liao WX, Roy AC, Ng SC (1999) Association of estrogen receptor gene polymorphisms with outcome of ovarian stimulation in patients undergoing IVF. Mol Hum Reprod 5: 797-802. http://dx.doi.org/ 10.1093/molehr/5.9.797.

Terman A (2005) Effect of the polymorphism of prolactin receptor (PRLR) and leptin (LEP) genes on litter size in Polish pigs. $J$ Anim Breed Genet 122: 400-404. http://dx.doi.org/10.1111/j.14390388.2005.00547.x.

Thuy NTD, Thuy NT, Cuong NV (2006) Genetic polymorphism of prolactin receptor gene in Mong Cai pig. Proceedings of International Workshop on Biotechnology in Agriculture 40-42.

Wollenhaupt K, Tomek W, Brussow KP, Tiemann U, Viergutz T, Schneider F, Nurnberg G (2002) Effects of ovarian steroids and epidermal growth factor (EGF) on expression and bioactivation of specific regulators of transcription and translation in oviductal tissue in pigs. Reproduction 123: 87-96. http://dx.doi.org/10.1530/ rep.0.1230087.

Zhang Y, Proenca R, Maffei M, Barone M, Leopold L, Friedman JM (1994) Positional cloning of the mouse obese gene and its human homologue. Nature 372: 425-432. http://dx.doi. org/10.1038/372425A0.

Zhang YH, Mei SQ, Peng XW, Zuo B, Lei MG, Xiong YZ, Li $\mathrm{FE}$ (2009) Molecular cloning and polymorphism of the porcine H2AFZ gene. Animal 3: 779-782. http://dx.doi.org/10.1017/ S1751731109004170.

Zucker LM, Zucker TF (1961) Fatty, a new mutation in the rat. J Hered 52: 275-278.

Zsolnai A, Orbán L (1999) Accelerated separation of random complex DNA patterns in gels: comparing the performance of discontinuous and continuous buffers. Electrophoresis 20: 1462-1468. http:// dx.doi.org/10.1002/(SICI)1522-2683(19990601)20:7<1462::AIDELPS1462>3.0.CO;2-0 